\title{
A new diterpene enone from the soldier beetle Cantharis livida (Coleoptera: Cantharidae)
}

\author{
Christophe Durvaux, ${ }^{\text {a }}$ Pascal Laurent, ${ }^{a}$ Désiré Daloze, ${ }^{a}$ Jean-Claude Braekman, ,,* Roland \\ Lupoli, ${ }^{b}$ Jean-Luc Dimarcq ${ }^{b}$ and Jacques Pasteels ${ }^{c}$ \\ ${ }^{a}$ Department of Organic Chemistry CP 160/06, Faculty of Sciences, University of Brussels, 50 \\ Av. F.D. Roosevelt, 1050 Brussels, Belgium \\ ${ }^{b}$ Entomed S.A., Tobias Stimmer Street, 67400 Illkirch, France \\ ${ }^{c}$ Laboratory of Cellular and Animal Biology, Faculty of Sciences, University of Brussels, 50 Av. \\ F.D. Roosevelt, 1050 Brussels, Belgium \\ E-mail: braekman@ulb.ac.be
}

Dedicated to Professor Alain Krief on the occasion of his $65^{\text {th }}$ birthday and retirement

\begin{abstract}
Cantharenone 1, a new diterpene structurally related to the prenylbisabolane skeleton, has been isolated from the beetle Cantharis livida (Cantharidae). Its structure has been determined on the basis of its spectral properties. This is the first report of such a type of diterpenoid from an insect.
\end{abstract}

Keywords: Cantharenone, Prenylbisabolane, Diterpene, Cantharidae, Coleoptera, Insecta

\section{Introduction}

During evolution, insects have acquired extremely diversified and sophisticated chemical defense systems that play a prominent role in their ecological success. Among the Coleoptera, the knowledge of the defensive chemistry of the Coccinellidae and the Chrysomelidae has grown significantly during the past decade. ${ }^{1-3}$ On the contrary, almost nothing is known about the chemistry of the Cantharidae (soldier beetles) despite the fact that many of them have aposematic colors and a well-developed system of defense glands in the prothorax and the abdomen.

In this paper, we report the isolation and structure determination of a new diterpene isolated from the $\mathrm{CH}_{2} \mathrm{Cl}_{2} / \mathrm{MeOH} \mathrm{1:1} \mathrm{extract} \mathrm{of} \mathrm{adults} \mathrm{(182} \mathrm{specimens)} \mathrm{of} \mathrm{Cantharis} \mathrm{livida} \mathrm{collected} \mathrm{near}$ Krasnodar (Caucasia, Russia). The adults of this carnivorous beetle can often be found on flowers in bloom while the larvae live at the soil surface among grass. 


\section{Results and discussion}

The extract was partitioned between the two phases of the mixture ethyl acetate-hexaneisopropanol-water 2:1.5:1:3. The resulting upper phase was evaporated to dryness and the oily residue chromatographed successively on two silica gel columns. This afforded, after a final purification by HPLC, $1.5 \mathrm{mg}$ of an oily UV absorbing diterpene for which the name cantharenone 1 was coined.
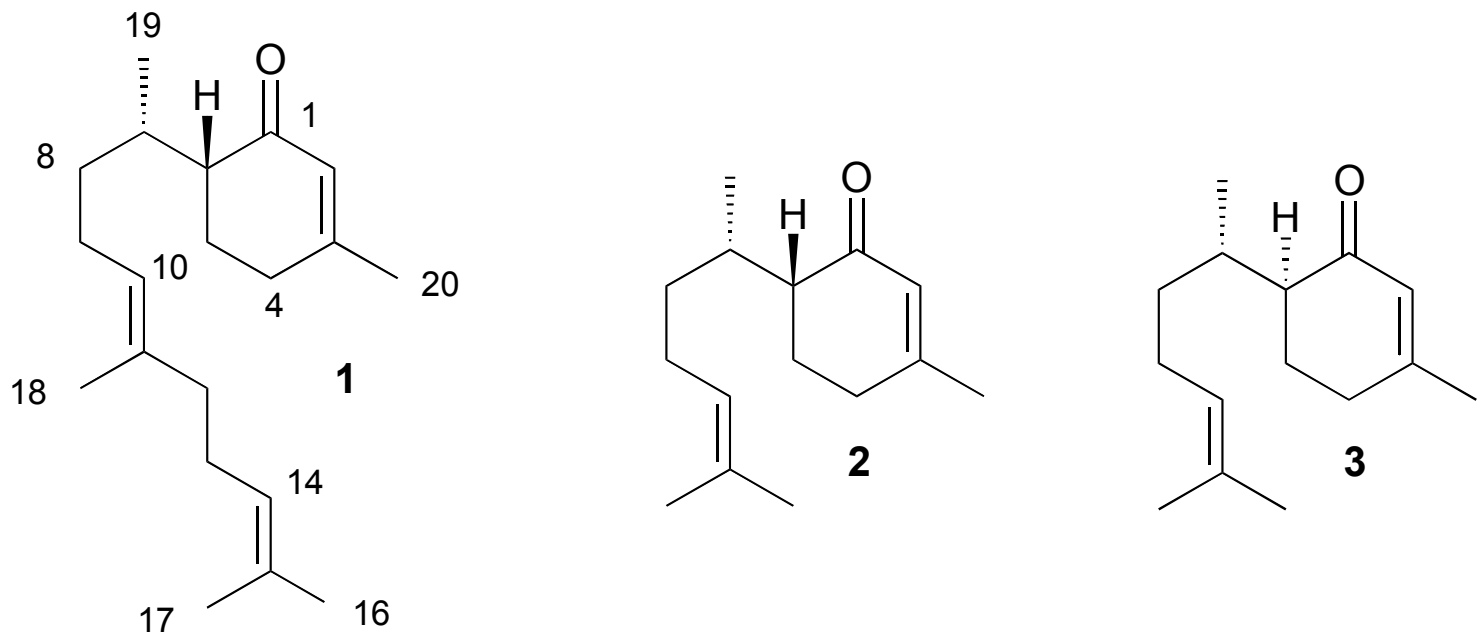

The HR-CIMS spectrum revealed its molecular formula to be $\mathrm{C}_{20} \mathrm{H}_{32} \mathrm{O}\left[(\mathrm{M}+\mathrm{H})^{+}\right.$at $\mathrm{m} / \mathrm{z}$ 289.2517; calcd for $\mathrm{C}_{20} \mathrm{H}_{33} \mathrm{O}$ 289.2531] requiring five double bond equivalents. Moreover, a detailed analysis of the 1D and 2D NMR spectra $\left({ }^{1} \mathrm{H}-{ }^{1} \mathrm{H}\right.$ COSY, HMQC, HMBC) indicated the presence of four methyl groups on double bond, of a secondary methyl group and of three trisubstituted double bonds one of which was involved in an enone system. It followed that cantharenone must be monocyclic. Comparison of the ${ }^{1} \mathrm{H}$ and ${ }^{13} \mathrm{C}$ NMR chemical shifts of cantharenone with those published by Hagiwara et $\mathrm{al}^{4}$ for (-)-2,10-bisaboladiene-1-one 2, a sesquiterpene isolated from Stevia purpurea ${ }^{5}$, indicated that they possessed the same C-1 to C-11 moiety with $\mathrm{H}_{3} \mathrm{C}-18, \mathrm{H}_{3} \mathrm{C}-19$ and $\mathrm{H}_{3} \mathrm{C}-20$ attached as shown. Moreover, the observation of a characteristic $\mathrm{HMBC}$ correlation between $\mathrm{H}-13$ and $\mathrm{C}-12$ confirmed that the fourth isoprenic unit is linked to the $\mathrm{C}-15$ unit as represented in $\mathbf{1}$.

In addition, the NMR chemical shifts reported for $\mathbf{2}$ are significantly different from those of its diastereoisomer $3{ }^{4}$ The same relative configurations as for $\mathbf{2}$ could thus be assign to C-6 and C-7 of cantharenone. Moreover, since compounds 1 and $\mathbf{2}$ have both negative specific rotatory power, they must have the same absolute configuration $6 R, 7 S^{4}$ 
Table 1. ${ }^{1} \mathrm{H}$ and ${ }^{13} \mathrm{C}$ NMR data of $1\left(600\right.$ and $75.4 \mathrm{MHz}, \mathrm{CDCl}_{3}, \delta$ from TMS, $J$ in $\left.\mathrm{Hz}\right)$

\begin{tabular}{ccc}
\hline Position & $\delta_{\mathrm{C}}$ & $\delta_{\mathrm{H}}$ \\
\hline 1 & 201.2 & - \\
2 & 127.4 & $5.86 \mathrm{~s}$ \\
3 & 161.2 & - \\
4 & 31.1 & $2.30 \mathrm{~m}$ \\
5 & 22.6 & 1.77 and $1.92 \mathrm{~m}$ \\
6 & 50.0 & $2.16 \mathrm{dt}(12,3.9)$ \\
7 & 30.6 & $2.34 \mathrm{~m}$ \\
8 & 34.9 & $1.30 \mathrm{~m}$ \\
9 & 26.1 & 1.95 and $2.05 \mathrm{~m}$ \\
10 & 124.5 & $5.12 \mathrm{t}(7.2)$ \\
11 & 135.2 & - \\
12 & 39.9 & 1.97 and $2.05 \mathrm{~m}$ \\
13 & 26.9 & 1.97 and $2.05 \mathrm{~m}$ \\
14 & 124.5 & $5.10 \mathrm{t}(7.2)$ \\
15 & 131.4 & - \\
16 & 17.8 & $1.60 \mathrm{~s}$ \\
17 & 25.8 & $1.68 \mathrm{~s}$ \\
18 & 16.1 & $1.59 \mathrm{~s}$ \\
19 & 15.8 & $0.80 \mathrm{~d}(6.6)$ \\
20 & 24.2 & $1.93 \mathrm{~s}$ \\
\hline
\end{tabular}

All of these data led us to structure $\mathbf{1}$ for cantharenone and to propose the complete NMR assignments reported in Table 1. Further structural arguments were given by the EIMS that presented two intense fragment ions at $\mathrm{m} / \mathrm{z} 137$ and 110 resulting from the loss from the molecular ion of a $\mathrm{C}_{11}$ (C7-C8 bond cleavage) and of a $\mathrm{C}_{13}$ carbon chain (McLafferty rearrangement, $\mathrm{C} 6-\mathrm{C} 7$ bond cleavage) respectively.

Meinwald et al. ${ }^{6}$ have reported the presence of 8-cis-dihydromatricaria acid in the defensive secretion of Chauliognathus lecontei. The Australian species C. pulchellus ${ }^{7}$ was found to contain the same acid in addition to the Coccinellidae alkaloids precoccinelline, hippodamine and propyleine and C. lugubris ${ }^{8}$ dihydromatricariate-based triglycerides, glyceride ethers and waxes. GC-MS analysis of the secretion of a few specimens of Cantharis livida collected near Brussels indicated that the secretion is a complex mixture of long chain derivatives probably related to matricaria acid in which the presence of cantharenone could not be confirmed. Due to the lack of material the mixture could not be studied further. At present, it is not possible to say if compound $\mathbf{1}$ is a true defensive compound of the beetle or is of exogenous origin as it may be also the case for the Coccinellid alkaloids found in Chauliognathus pulchellus ${ }^{7}$. 


\section{Experimental Section}

General Procedures. EIMS, HR-CIMS $\left(\mathrm{NH}_{3}\right)$ and GC-EIMS analyses were performed with a Micromass Autospec 3F instrument $(70 \mathrm{eV})$ coupled to a gas chromatograph equipped with a 25 $\mathrm{m} \times 0.25 \mathrm{~mm}$ CP Sil 5 capillary column (Chrompack), at $40{ }^{\circ} \mathrm{C}(4 \mathrm{~min})$, programmed to $200{ }^{\circ} \mathrm{C}$ at $8{ }^{\circ} \mathrm{C} \mathrm{min}^{-1}$ (hold $5 \mathrm{~min}$ at $200{ }^{\circ} \mathrm{C}$ ), then to $300{ }^{\circ} \mathrm{C}$ at $15^{\circ} \mathrm{C} \mathrm{min}^{-1}$ (hold $5 \mathrm{~min}$ at $300^{\circ} \mathrm{C}$ ); the carrier gas was helium. In all cases, peak intensities are expressed as \% relative to the base peak. The ${ }^{1} \mathrm{H}$ NMR spectra were recorded in $\mathrm{CDCl}_{3}$ at $300 \mathrm{MHz}$ with a Bruker Avance TM 300, or at $600 \mathrm{MHz}$ using a Varian Unity 600 instrument and are reported in ppm from internal TMS on the $\delta$ scale. The ${ }^{13} \mathrm{C}$ NMR spectra were recorded in $\mathrm{CDCl}_{3}$ at $75.4 \mathrm{MHz}$ with a Bruker Avance TM 300 instrument. The IR spectra were recorded with a Bruker IFS 25 instrument as film on a $\mathrm{NaCl}$ disk and the UV/Vis spectra with a Philips PU 8700 spectrophotometer in a $1 \mathrm{~cm}$ cell. Optical rotations were recorded at $589 \mathrm{~nm}$ (sodium D line) in a $1 \mathrm{dm}$ cell at $23{ }^{\circ} \mathrm{C}$ on an Atago AP-100 polarimeter. Thin layer chromatography analyses (TLC) were performed with $0.25 \mathrm{~mm}$ Polygram silica gel SILG/UV254 precoated plates (Macherey-Nagel). Column chromatographies were performed on silica gel (MN Kieselgel $600.04-0.063 \mathrm{~mm}$ ) using the flash technique. HPLC analyses were performed on a Waters LC module 1 apparatus equipped with a Lichrospher Si 60 column (Merck, $25 \mathrm{~cm}, 5 \mu, 1 \mathrm{~mL} / \mathrm{min}$, hexane/ethyl acetate 95:5, detection at $\lambda=320 \mathrm{~nm}$ ) and a Waters 996 Photodiode Array detector.

Isolation and characterization of cantharenone 1. 182 beetles collected near Krasnodar (Caucasia, Russia) were lyophilised and stored in methanol. After elimination of the solvent by filtration on a cotton wool, the beetles were crushed in $10 \mathrm{~mL}$ of the mixture $\mathrm{CH}_{2} \mathrm{Cl}_{2} / \mathrm{MeOH}$ 1:1 and filtered. The solid residue was then exhaustively extracted with $\mathrm{MeOH}(3 \times 5 \mathrm{~mL})$ and $\mathrm{CH}_{2} \mathrm{Cl}_{2}(3 \times 5 \mathrm{~mL})$. After evaporation of the combined organic phases, the resulting oily residue was partitioned between the two phases of the mixture ethyl acetate/hexane/isopropanol/water $2: 1.5: 1: 3$. The solid residue $(362 \mathrm{mg}$ ) obtained after evaporation of the upper phase was submitted to two successive flash column chromatographies on silica gel (eluents: hexane/acetone $98: 2$ to $80 / 20$ and toluene). The fractions containing cantharenone were further purified by HPLC. This led to the isolation of $1.5 \mathrm{mg}$ of compound $\mathbf{1}$.

Cantharenone 1: $[\alpha]_{\mathrm{D}}{ }^{23}-31\left(c 0.11, \mathrm{CHCl}_{3}\right)$; UV (MeOH): $\lambda_{\max } 270 \mathrm{~nm}(\varepsilon$ 14,480); IR: 2924, 1668, 1558, $1456 \mathrm{~cm}^{-1}$, EIMS: $\mathrm{M}^{+}$at $m / z 288$ (2), fragment ions at $m / z 149$ (11), 137 (95), 135 (40), 110 (74), 109 (100), 95 (17), 82 (19), 81 (27), 69 (70), 67 (28), 55 (35) and 53 (18); ${ }^{1} \mathrm{H}$ and ${ }^{13}$ C NMR: see Table 1.

\section{Acknowledgements}

We thank Dr. M. Luhmer and R. d'Orazio for the NMR spectra and M. Pamart for the mass spectra. 


\section{References}

1. Daloze, D.; Braekman, J.C.; Pasteels, J.M. Chemoecology 1994 \& 1995, 5/6, 173.

2. Laurent P.; Braekman J.C.; Daloze, D. Topics Curr. Chem. 2004, 240, 167.

3. Laurent P.; Braekman J.C.; Daloze, D.; Pasteels, J.M. Eur. J. Org. Chem. 2003, 2733.

4. Hagiwara, H.; Okabe, T.; Ono, H.; Kamat, V.P., Hoshi, T.; Suzuki, T.; Ando, M. J. Chem. Soc., Perkin Trans 1 2002, 895.

5. Bohlmann, F.; Zdero, C.; Schoneweiss, S. Chem. Ber. 1976, 109, 3366.

6. Meinwald, J.;Meinwald, Y.C.; Chalmers, A.M.; Eisner, T. Science 1968, 160, 890.

7. Moore, B.P.; Brown, W.V. Insect Biochem. 1978, 8, 393.

8. Brown, W.V.; Lacey, M.J.; Moore, B.P. J. Chem. Ecol. 1988, 14, 411. 